\title{
Application of DPSIR framework to access environmental impact of white limestone mining and processing in Luc Yen, Yen Bai province
}

\author{
Úng dụng mô hình DPSIR đánh giá tác động môi trường của hoạt động khai \\ thác và chế biến đá vôi trắng ở huyện Lục Yên, tỉnh Yên Bái
}

Research article

Nguyen Thi Cuc*, Nguyen Phuong, Nguyen Quoc Phi, Phan Thi Mai Hoa

Department of Environmental Sciences, Faculty of Environment, Hanoi University of Mining and Geology, Duc Thang ward, North Tu Liem district, Ha Noi, Vietnam

\begin{abstract}
Application of DPSIR framework (Drivers, Pressures, States, Impacts and Responses) aims to assess the current impact of the environment through a process starting with "driving forces" through "pressures" to "states" and "impacts" eventually leading to political "responses" in mineral mining in Luc Yen district. Research results show that the main drivers in Luc Yen are resources consumption ( $\mathrm{Wi}=3.675)$, the demand for industrial development $(\mathrm{Wi}=3.575)$, followed by diversification and size of mines $(\mathrm{Wi}=3.250)$. The environmental pressures are solid $(\mathrm{Wi}=4.025)$, dust $(\mathrm{Wi}=3.900)$ and wastewater $(\mathrm{Wi}=3.625)$. The current state of environment is the most affected by air (Wi = 3.400). The soil and water are almost unaffected. The current environmental impacts have positive and negative social, economic and environmental impacts. Specifically, the positive impacts are employment opportunities, income $(\mathrm{Wi}=3.325)$ and an increase in state budget $(\mathrm{Wi}=$ 3.000). There are no positive improvements of the environment related to mining activities, such as negative impacts on ecological landscape $(\mathrm{Wi}=3.050)$ and infrastructure $(\mathrm{Wi}=3.075)$. Improving environmental quality and mitigating environmental impacts have been applied, including innovative technology $(\mathrm{Wi}=3.175)$, pollution monitoring and environmental quality monitoring (Wi $=3.400$ ). Communication activities to enhance community participation in Luc Yen area were also highly appreciated by people $(\mathrm{Wi}=3.375)$.
\end{abstract}

Việc úng dụng mô hình DPSIR (Drivers, Pressures, States, Impacts and Responses) nhằm muc đích đánh giá tác động môi truòng theo một quá trình tù động lực, áp lực, hiện trạng và tác động đến đáp ứng để giải quyết vấn đề môi truờng liên quan đến hoạt động khai thác khoáng sản tại huyện Luc Yên. Kết quả nghiên cứu cho thấy động lực dẫn tới hoạt động khai thác đá vôi trắng tại huyện Luc Yên là nhu cầu sủ dụng tài nguyên (Wi =3,675), nhu cầu phát triển hoạt động công nghiệp ( $W i=3,575)$, tiếp đến là sự đa dạng, quy mô các mỏ khoáng (Wi = 3,250). Áp lục môi truờng là chất thải rắn $(W i=4,025)$, tiếp đến là bụi $(W i=3,900)$ và nuoớc thải $(W i=3,625)$. Hiện trạng môi trương tụ nhiên hiện nay tại khu vục Lục Yên chịu ảnh huởng mạnh nhất là không khí (trọng số $W i=3,400)$, môi truờng đất và nước gần nhu chua bị tác động. Tác động môi truòng hiện nay tại huyện Luc Yên thể hiện qua tác động đến môi truò̀ng xã hội và môi truờng tụ nhiên. Cu thể, tác động giải quyết việc làm, tăng thu nhập $(W i=3,325)$ và tăng ngân sách nhà nuớc (Wi = 3,000). Tác động tiêu cục tới cảnh quan sinh thái $(W i=3,050)$ và co sở ha tầng $(W i=3,075)$. Các giải pháp cải thiện và giảm thiểu tác động môi trương đã áp dụng hiện nay là đổi mới công nghệ khai thác theo huoóng tiên tiến $(W i=3,175)$, giám sát ô nhiếm và quan trắc chất luợng môi truòng $(W i=3,400)$. Giải pháp truyền thông tăng cuờng sụ tham gia của công đồng tại khu vục Lục Yên cũng được người dân đánh giá cao với trọng số (Wi $=3,375)$.

Keywords: DPSIR, $\mathrm{W}_{\mathrm{i}}$, Luc Yen 


\section{Introduction}

One of the greatest facing problems nowadays in Luc Yen is environmental pollution caused by mining and mineral processing. At present, 28 mines in Luc Yen area were licensed for mining, and 14 other mines were being explored. When 128 mines are operational, it will be difficult to manage and monitor the environment, especially audit when mining is completed. Therefore, in order to improve the effectiveness of environmental management in mining area in Luc Yen district, DPSIR framework is used to study the causes, effects, states, and responses of the study area to the environmental change in mining activities.

Currently, DPSIR framework has been applied by many countries to solve problems related to environmental degradation, water, soil and mining. Specifically, the increased use of scarce metals in combination with climate changes pave way for extensive extraction of mineral resources in Greenland [3]. The focus of the study in Greenland is on environmental ethical aspects of mining activities in a vulnerable and unspoiled arctic nature. Greenland has adopted this framework to give an overview of environmental issues arising from mineral exploitation, to develop a sustainable mining strategy in the future. The DPSIR framework has been used to assess the mining pressures and associated measures in European countries [1]. In Vietnam, the DPSIR framework was applied to develop National Environmental Indicators [2] and national state of environmental reports from 2011 to 2015 [4]. In mining industry, some authors such as Nguyen Thi Ha, Nguyen Quoc Phi deployed the framework for environmental assessment of mineral exploitation in Ba Ria-Vung Tau province [5] [6]. However, indicators were developed mainly for excavation of building stones and should be revised to meet the diverse characteristics of mining activities in Luc Yen. Based on applying the DPSIR, it will help the management agency to identify the causes, environmental status and the ability to cope with environmental problems caused by mining activities. Furthermore, it also identifies shortcomings and provides suitable solutions for sustainable mining of the area.

\section{Methods}

In this study, the DPSIR framework was applied in identifying, analyzing and evaluating environmental issues related to mineral exploitation in Luc Yen area through a sequence of environmental changes. (D) The driving forces are described as needs, which can be either economic or social. (P) the consequences of the driving forces are defined as pressures, which can be positive and negative. However, the main focus is generally on the negative aspects of the environment. (S) The pressures will change the state of the environment. (I) When the state of the environment changes due to mining activities, it might have positive and negative social, economic or environmental impacts, such as changes in habitat and ecosystems. $(\mathrm{R})$ there are a number of potential adaptive or mitigative responses to minimize the negative impacts of mining. The five indicator groups of DPSIR are de- signed in Table 1, each of which is rated on a 5-point Likert scale (level 1- very low; level 5 - very high).

Based on the 5-point Likert scale, questionnaires were constructed and processed according to descriptive statistics as follows:

- Mean value (wMean) is defined as the mean of the overall agreement. (wMean) for 5-point Likert scale is calculated as follows:

$$
w \text { Mean }=\sum_{i=1}^{5} X_{i} P_{i}\left(X_{i}\right)
$$

The (wMean) results were compared on a scale. Each scale point could be labelled according to its level: $(1.000-1.499)=$ Very low, $(1.500-2.499)=$ low,$(2.500$ $3.499)=$ medium, $(3.500-4.499)=$ high, $(4.500-5.000)=$ very high [Zhu, 2008].

- Standard deviation (wStD) for 5- point Likert scale is calculated as follows:

$$
w S t D=\sqrt{\sum_{i=1}^{5} \frac{\left(X_{i}-w \text { Mean }\right)^{2}}{N}}
$$

- Consensus $(\mathrm{CnS})$ is defined as the agreement towards a declarative statement among the individuals of a sample group. $(\mathrm{CnS})$ for 5-point Likert scale is calculated as follows [Tastle and Wierman, 2007]:

$$
C n S(X)=1+\sum_{i=1}^{5} P_{i}\left(X_{i}\right) \log _{2}\left(1-\frac{\left|X_{i}-w M e a n\right|}{d_{x}}\right) \text { (3) }
$$

Where $\mathrm{X}$ is the response, $\mathrm{n}$ is the number of the categories in an ordinal scale, $x_{i}$ is the degree of agreement in category $i, P_{i}$ is the probability of the occurrence of $x_{i} ; d_{x}=$ $\mathrm{X}_{\max }-\mathrm{X}_{\min }$ is the width of categories on the measurement scale, and wMean is the mean of the overall agreement. Applying to the traditional 5-point Likert scale, it is find that $\mathrm{N}=5$, i ranges from 1 to 5 , and $\mathrm{d}_{\mathrm{x}}=5-1=4$.

Through the community consultation with 30 people, 5 workers in the mining sector in Luc Yen, and 5 managers in Yen Bai Environmental monitoring Center, the study analyzed and assessed the environmental issues related to mining activities in the area using 5 indicator groups: driving forces, pressures, states, impacts, and responses to environmental changes in the research area.

\section{Results and discussion}

\subsection{Driving forces}

Through the evaluation of the people in Luc Yen, the activities of resource consumption achieved with the highest mean of 3.675 , followed by that of commercial industry (3.575) and diversification of mineral resources (3.250) The remaining issues such as natural population growth, employment pressures, unemployment, and agricultural development were the next driving forces. The agricultural development received the highest consensus of 0.72 , which was followed by the employment pressures (0.717 and natural population growth $(0.701)$. It is clear that the indicators achieving the standard deviation value (wStD) were higher than others, while these same indicators had low consensus values. The indicators with high 
standard deviation have lower consensus values than others.

To sum up, the industrial, commercial activities and natural resource consumption were the most important driving forces, which effected on an increase in the mining activities in Luc Yen. The population growth and employment pressures or urbanization were not the major driving forces with means below the average.

Table 1. The value of driving forces of environmental effect in Luc Yen, Yen Bai

\begin{tabular}{|c|c|c|c|c|c|c|c|c|c|}
\hline \multirow[b]{2}{*}{ No. } & \multirow[b]{2}{*}{ Indicator } & \multicolumn{5}{|c|}{ Selection probability in Likert scale } & \multirow{2}{*}{$\mathbf{w M}$} & \multirow[b]{2}{*}{ wStD } & \multirow{2}{*}{ CnS } \\
\hline & & 1 & 2 & 3 & 4 & 5 & & & \\
\hline 1 & $\begin{array}{l}\text { The process of natural population growth and } \\
\text { immigration }\end{array}$ & 0.075 & 0.525 & 0.325 & 0.025 & 0.05 & 2.450 & 0.536 & 0.701 \\
\hline 2 & Employment pressure, unemployment & 0.175 & 0.45 & 0.35 & 0 & 0.025 & 2.250 & 0.566 & 0.717 \\
\hline 3 & Urbanization & 0.200 & 0.375 & 0.350 & 0.075 & 0.000 & 2.300 & 0.558 & 0.687 \\
\hline 4 & Industrial and commercial activities & 0.050 & 0.025 & 0.325 & 0.500 & 0.100 & 3.575 & 0.540 & 0.690 \\
\hline 5 & Agricultural Development & 0.200 & 0.400 & 0.375 & 0.025 & 0.000 & 2.225 & 0.570 & 0.723 \\
\hline 6 & Natural resources Consumption & 0.075 & 0.075 & 0.150 & 0.500 & 0.200 & 3.675 & 0.554 & 0.605 \\
\hline 7 & Diversification of mineral resources & 0.100 & 0.225 & 0.150 & 0.375 & 0.150 & 3.250 & 0.508 & 0.508 \\
\hline
\end{tabular}

\subsection{Pressures}

The major pressures from an operating mining industry in Luc Yen were emissions of solid waste with mean value was 4.025 , followed by dust, wastewater, and forest degradation. In general, these were the indicators that got a high consensus from the consultation. As can be seen from table 2 , the consensus values $(\mathrm{CnS})$ of indicators ranged from 0.570 to 0.665 . This result is consistent with the survey, because marbles processing to produce paving stones in Luc Yen were mainly exploited by diamond wire technology. Besides, water was recycled, so wastewater in mineral mining was reduced significantly.
Remaining indicators such as loss of agricultural land, residential area, production, and service area showed an average consensus value.

The environmental pressures from an overuse of resources as well as the loss of forest area and land of agricultural production were the major problems in the local area. However, the greatest environmental pressure on mining activities was emissions of waste coming from the mining and processing in the mines. Table 2 shows that emission of solid waste was calculated with the highest mean of 4.025, which was followed by that of dust (3.900) and wastewater (3.625).

Table 2. The value of pressures on environment in Luc Yen, Yen Bai

\begin{tabular}{|c|c|c|c|c|c|c|c|c|c|}
\hline \multirow[b]{2}{*}{ No. } & \multirow{2}{*}{ Indicator } & \multicolumn{5}{|c|}{ Selection probability in Likert scale } & \multirow{2}{*}{$\mathbf{w M}$} & \multirow[b]{2}{*}{ wStD } & \multirow{2}{*}{$\mathrm{CnS}$} \\
\hline & & 1 & 2 & 3 & 4 & 5 & & & \\
\hline 1 & Decline of forest area & 0.075 & 0.025 & 0.2 & 0.55 & 0.15 & 3.675 & 0.554 & 0.653 \\
\hline 2 & Loss of land of agricultural production & 0.15 & 0.125 & 0.325 & 0.3 & 0.1 & 3.075 & 0.501 & 0.568 \\
\hline 3 & Loss of residential production. service areas & 0.100 & 0.325 & 0.325 & 0.125 & 0.125 & 2.850 & 0.503 & 0.580 \\
\hline 4 & Decline of metal mineral resources & 0.150 & 0.275 & 0.275 & 0.150 & 0.150 & 2.875 & 0.502 & 0.517 \\
\hline 5 & Decline of non-metallic mineral resources & 0.075 & 0.175 & 0.275 & 0.225 & 0.250 & 3.400 & 0.520 & 0.513 \\
\hline 6 & Solid waste & 0.100 & 0.050 & 0.000 & 0.425 & 0.425 & 4.025 & 0.618 & 0.570 \\
\hline 7 & Wastewater & 0.050 & 0.075 & 0.300 & 0.350 & 0.225 & 3.625 & 0.547 & 0.607 \\
\hline 8 & Dust & 0.025 & 0.075 & 0.175 & 0.425 & 0.300 & 3.900 & 0.593 & 0.665 \\
\hline
\end{tabular}

\subsection{States}

The states that were strongly affected by pressures are air quality, water quality as shown by a mean of 3.400 and 3.225 respectively. The mean score for the soil quality, biodiversity decline, environmental incident, etc. were low among others; and that indicators showed a low consensus between 0.468 and 0.596 (Table 3).

Statistical results from experts and people showed that the impact of mining activities on the general environment in Luc Yen was not too large. However, issues of geological hazards such as landslide of bench face in mine site, waste dump as well as impacts on the water and air quali- ty will need to be considered when increasing more and more mining activities in the future.

\subsection{Impacts}

When the state of the environment changes due to mining activities, it might have both positive and negative impacts. The positive impacts are social and economic improvements of society such as employment opportunity, increase in income, source of revenue for the state budget as shown by a mean of 3.00 and 3.325 respectively, while that had a high consensus of 0.303 and 0.717 respectively. Mining activities also impacted negatively on ecological landscapes and infrastructure such as roads, public infrastructures with a mean of 3.050 and 3.075 respectively. 
However, negative impacts on infrastructure were recorded an average consensus of 0.460 .

Table 4 showed that negative impacts on human health, ecological landscape had an average consensus. However, the positive impacts such as the development of sources of revenue for local budgets as well as the improvement of the quality of life have not been appreciated. The best positive impact resulting from mining activities was the employment opportunity. Therefore, in order to ensure fairness as well as an increase on transparency in mining activities, local authorities should be ensured improve living standards.

Table 3. The value of states of environment in Luc Yen, Yen Bai

\begin{tabular}{llcccccccc}
\multirow{2}{*}{ No. Indicator } & \multicolumn{4}{c}{ Selection probability in Likert scale } & \multicolumn{2}{c}{ wM } & wStD & CnS \\
\cline { 2 - 7 } & & 1 & 2 & 3 & 4 & 5 & & & \\
\hline $\mathbf{1}$ & Soil quality & 0.175 & 0.4 & 0.375 & 0.025 & 0.025 & 2.325 & 0.554 & 0.690 \\
$\mathbf{2}$ & Water quality & 0.1 & 0.175 & 0.325 & 0.2 & 0.2 & 3.225 & 0.506 & 0.532 \\
$\mathbf{3}$ & Air quality & 0.050 & 0.225 & 0.150 & 0.425 & 0.150 & 3.400 & 0.520 & 0.561 \\
$\mathbf{4}$ & Biodiversity decline & 0.175 & 0.325 & 0.325 & 0.125 & 0.050 & 2.550 & 0.525 & 0.601 \\
$\mathbf{5}$ & Landslide of bench face, waste dump & 0.100 & 0.200 & 0.325 & 0.275 & 0.100 & 3.075 & 0.501 & 0.596 \\
$\mathbf{6}$ & Other environmental incident & 0.275 & 0.350 & 0.175 & 0.200 & 0.000 & 2.300 & 0.558 & 0.596 \\
$\mathbf{7}$ & Diseases caused by mining activities & 0.200 & 0.225 & 0.225 & 0.200 & 0.150 & 2.875 & 0.502 & 0.468
\end{tabular}
(noise pollution. exhaust gas. digestive diseases. skin ...)

Table 4. The value of impacts on socio-economic development in Luc Yen, Yen Bai

\begin{tabular}{|c|c|c|c|c|c|c|c|c|c|}
\hline \multirow{2}{*}{ No. } & \multirow{2}{*}{ Indicator } & \multicolumn{5}{|c|}{ Selection probability in Likert scale } & \multirow{2}{*}{$\mathbf{w M}$} & \multirow{2}{*}{ wStD } & \multirow{2}{*}{$\mathrm{CnS}$} \\
\hline & & 1 & 2 & 3 & 4 & 5 & & & \\
\hline 1 & Employment opportunity and income & 0.025 & 0.175 & 0.375 & 0.3 & 0.125 & 3.325 & 0.513 & 0.643 \\
\hline 2 & $\begin{array}{l}\text { Increase in source of revenues for the } \\
\text { state budget }\end{array}$ & 0.025 & 0.275 & 0.425 & 0.225 & 0.05 & 3.000 & 0.500 & 0.717 \\
\hline 3 & Social and economic improvements & 0.175 & 0.325 & 0.325 & 0.175 & 0.000 & 2.500 & 0.530 & 0.637 \\
\hline 4 & $\begin{array}{l}\text { Impacts on the house, the property of } \\
\text { the people }\end{array}$ & 0.175 & 0.300 & 0.375 & 0.075 & 0.075 & 2.575 & 0.522 & 0.597 \\
\hline 5 & $\begin{array}{l}\text { Impacts on infrastructure (roads, } \\
\text { Bridges, public works ...) }\end{array}$ & 0.200 & 0.125 & 0.275 & 0.200 & 0.200 & 3.075 & 0.501 & 0.460 \\
\hline 6 & Impacts on the landscape, ecology & 0.125 & 0.250 & 0.250 & 0.200 & 0.175 & 3.050 & 0.500 & 0.509 \\
\hline 7 & Impacts on human health & 0.275 & 0.350 & 0.125 & 0.050 & 0.075 & 1.925 & 0.628 & 0.618 \\
\hline
\end{tabular}

\subsection{Responses}

There are a number of potential adaptive or mitigative responses that decision-makers could take to minimize the negative impacts of mining. Setting pollution and environmental quality monitoring were calculated with a mean value of 3.400; and changing advanced technology with a mean score of 3.175 . About environmental communication, community participation was highly appreciated as shown by a consensus value of 0.700 . Institutional and social policy measures, and development planning in the study area have not been effectively demonstrated with a mean of 2.675 and 2.375 respectively.

Table 5 showed that the solutions to ensure environmental sustainability including the monitoring as well as an increase on community participation had the highest consensus score (0.700). Solutions on technological innovation or on policies and laws needed to have active participation from local authorities and the mining and processing enterprises. However, those were not highly appreciated due to their feasibility.

\section{Table 5. The value of Responses in Luc Yen, Yen Bai}

\begin{tabular}{|c|c|c|c|c|c|c|c|c|c|}
\hline \multirow[t]{2}{*}{ No. } & \multirow[t]{2}{*}{ Indicator } & \multicolumn{5}{|c|}{ Selection probability in Likert scale } & \multirow[t]{2}{*}{$\mathbf{w M}$} & \multirow[t]{2}{*}{ wStD } & \multirow[t]{2}{*}{$\mathrm{CnS}$} \\
\hline & & 1 & 2 & 3 & 4 & 5 & & & \\
\hline 1 & Environmental rehabilitation and restoration & 0.3 & 0.45 & 0.125 & 0.05 & 0.075 & 2.150 & 0.583 & 0.606 \\
\hline 2 & Treatment Technologies & 0.2 & 0.275 & 0.3 & 0.2 & 0.025 & 2.575 & 0.522 & 0.585 \\
\hline 3 & Advanced mining technologies & 0.125 & 0.125 & 0.350 & 0.250 & 0.150 & 3.175 & 0.504 & 0.558 \\
\hline 4 & $\begin{array}{l}\text { Pollution and environmental quality monitor- } \\
\text { ing }\end{array}$ & 0.075 & 0.125 & 0.275 & 0.375 & 0.150 & 3.400 & 0.520 & 0.583 \\
\hline 5 & $\begin{array}{l}\text { Measures on policies. institutions and laws on } \\
\text { environmental protection }\end{array}$ & 0.200 & 0.225 & 0.375 & 0.100 & 0.100 & 2.675 & 0.513 & 0.554 \\
\hline 6 & Measure on development planning & 0.175 & 0.425 & 0.300 & 0.050 & 0.050 & 2.375 & 0.547 & 0.645 \\
\hline
\end{tabular}




\begin{tabular}{llccccccccc} 
No. Indicator & \multicolumn{3}{c}{ Selection probability in Likert scale } & wM & \multirow{2}{*}{ wStD } & CnS \\
\cline { 3 - 7 } & & 1 & 2 & 3 & 4 & 5 & & & & \\
\hline $\mathbf{7}$ & Environmental education and communication & 0.050 & 0.250 & 0.525 & 0.175 & 0.000 & 2.825 & 0.504 & 0.751 \\
$\mathbf{8}$ & An increase on community participation & 0.000 & 0.175 & 0.325 & 0.450 & 0.050 & 3.375 & 0.517 & 0.700
\end{tabular}

\section{Conclusion}

Results show that, the impacts of mining activities on the environment in Luc Yen are assessed based on opinions of people living near the mine, employees working at the mining area as follows:

The driving forces for mineral exploitation in Luc Yen area was resources consumption $\left(\mathrm{W}_{\mathrm{i}}=3.675\right)$, which was followed by the demand for industrial development $\left(\mathrm{W}_{\mathrm{i}}=\right.$ $3.575)$ and the diversity of the mines $\left(\mathrm{W}_{\mathrm{i}}=3.250\right)$.

The major environmental pressures in Luc Yen were solid wastes and the emission of dust particles to the air. The amount of solid wastes including mine tailings and rock dumps was greatest pressure for the environment with mean weight of 4.025 . Three main sources of dust come from drilling, blasting operations, and the transport process $\left(\mathrm{W}_{\mathrm{i}}=3.900\right)$. The amount of polluted water during the extraction process was mainly rainwater runoff and water for dust control $\left(\mathrm{W}_{\mathrm{i}}=3.625\right)$.

The state in Luc Yen that was most affected by pressures was air quality $\left(\mathrm{W}_{\mathrm{i}}=3.400\right)$ resulting from the process of mineral exploitation and transportation. The lowest mean score, for soil quality, was 2.325 because the exploitation activities in Luc Yen are mainly white limestone. New exploitation technology does not use toxic chemicals, therefore the mining activities do not affect the soil and water quality significantly.

When the state of the environment changes due to mining activities, it might have both positive and negative social and environmental impacts. The positive impact was employment opportunity with a mean of 3.325 , which was followed by income $\left(\mathrm{W}_{\mathrm{i}}=3.325\right)$ and an increase in state budget $\left(\mathrm{W}_{\mathrm{i}}=3.000\right)$. The negative impacts were destruction of ecological landscape $\left(\mathrm{W}_{\mathrm{i}}=3.050\right)$ and infrastructure $\left(\mathrm{W}_{\mathrm{i}}=3.075\right)$.

Innovative technology solutions, such as new technologies $\left(\mathrm{W}_{\mathrm{i}}=3.175\right)$, pollution and environmental quality monitoring $\left(\mathrm{W}_{\mathrm{i}}=3.400\right)$ were highly evaluated. Specifically, most of the white limestones were mined by the diamond wire technology. This technology helped to lessen emission of dust particles to air during the mining process, and keep the rock mass undisturbed. Communi- cation measures to enhance community participation in Luc Yen area were also highly appraised by villagers $\left(\mathrm{W}_{\mathrm{i}}\right.$ $=3.375)$.

\section{References}

[1] Briere B. and Turrell J., 2012. Task 3e - Mining. In 3rd Implementation Report on the Water Framework Directive - River Basin Management Plans (RBMPs). European Environment Agency (EEA), $37 \mathrm{pp}$.

[2] Can L.T, 2005. Overview of applying the DPSIR model for environmental inicators development. Ministry of Natural Resources and Environment Viet Nam, Hanoi. (Tổng quan về ứng dụng mô hình DPSIR trong xây dựng chỉ thị môi trường).

[3] Hansen S. H, 2013. Environmental and Ethical Aspects of Sustainable Mining in Greenland. Journal of Earth Science and Engineering 3, 213-224.

[4] Ministry of Natural Resources and Environment Viet Nam, 2015. The National State of environment 2015. (Báo cáo hiện trạng môi trường quốc gia 2015).

[5] Nguyen Thi Ha, 2016. The status and solutions for environmental protection for mineral exploitation at Tan Thanh district, Ba Ria - Vung Tau province. Unpublished master's thesis. Hanoi University of Mining and Geology, 109pp.

[6] Nguyen Quoc Phi, Nguyen Phuong, Nguyen Thi Ha, $\mathrm{Vu}$ Thi Lan Anh, Nguyen Thi Cuc, 2016. Application of DPSIR model to evaluate the environmental status of mining sites at Tan Thanh, Ba Ria - Vung Tau province. Workshop on Environmental assessment and hazard analysis of mining areas in Central Vietnam. Hanoi, pp.40-53.

[7] Tastle W. J. and Wierman M. J., 2007. Consensus and dissention: A measure of ordinal dispersion. International Journal of Approximate Reasoning 45, 531-545.

[8] Zhu L., 2008. The Institutional Environment for B2B E-commerce Adoption. Doctoral Dissertation. University of Arizona, US, 320pp. 